\title{
AGELANIUS CHILOENSIS, A NEW SPECIES OF HORSE FLY FROM SOUTHERN CHILE (DIPTERA: TABANIDAE)
}

\section{AGELANIUS CHILOENSIS, UNA NUEVA ESPECIE DE TÁBANO DEL SUR DE CHILE (DIPTERA: TABANIDAE)}

\author{
Christian R. González \\ Instituto Entomología, Universidad Metropolitana de Ciencias de la Educación, Código Postal 7760197, Santiago, \\ Chile.christian.gonzalez@umce.cl
}

\begin{abstract}
The female of Agelanius chiloensis, new species, from southern Chile is described and illustrated. Its relationships with other species of Agelanius are discussed.
\end{abstract}

KEYwords: Agelanius chiloensis sp.n., Diachlorini, Neotropical Region, Tabanomorpha.

\section{RESUMEN}

La hembra de Agelanius chiloensis, nueva especie del sur de Chile, es descrita e ilustrada. Sus relaciones con otras especies de Agelanius son discutidas.

Palabras Clave: Agelanius chiloensis sp.n., Diachlorini, Región Neotropical, Tabanomorpha.

\section{INTRODUCTION}

A total of 1,172 species of Tabanidae are known from the Neotropical Region (Fairchild \& Burger 1994). For Chile there are records of 16 genera and 115 species (Coscarón \& González 1991; González 2000). The genus Agelanius was erected by Rondani (1863) as a monotypic genus, including only $A$. meridianus Rondani. Kröber (1930) listed Agelanius as a subgenus of Tabanus L. Later, Stone (1944) considered Agelanius as synonymous of Dasybasis Macquart. Coscarón \& Philip (1967) reviewed the neotropical species of Dasybasis and considered Agelanius as a subgenus of Dasybasis Macquart. González (1999) revised the taxa considered subgenera of Dasybasis by Coscarón \& Philip (1967) and based on morphological differences from Dasybasis s.s. raised to generic status the taxon Agelanius Rondani. Currently, Agelanius currently comprises 11 species distributed in southern South America, from Santiago Province to the Región de Aysén in Chile and in the Argentinean provinces of Neuquén and Chubut.

The genus Agelanius, is endemic to southern South America (Fairchild \& Burger 1994). It is considered to be part of the most primitive group within the tribe Diachlorini, due to they may resemble more closely a hypothetical ancestral type like as Dasybasis and Stenotabanus Lutz (Fairchild 1969). Agelanius can be recognized by the following characters: brown medium-sized species; front narrow, frontal callus keel-shaped and not touching eyes; eyes pilose, without bands; basal flagellomere without dorsal prolongation; maxillary palpi slender and elongate; subcallus without hairs; mesoscutum with narrow, pale stripes; abdomen brown and generally with pale triangles on some tergites; cerci subcircular; gonapophysis with border concave and 
weakly projected; sternite VIII with wide, straight base; spermathecal ducts long (González 1999). In Chile, species are distributed from Santiago Province to Aysén (González \& Henry 1996). In Argentina, they are distributed from Neuquén to Chubut (González 1999).

This paper is a contribution toward a better knowledge of the fauna of southern South America. Its purpose is to describe the adult female of a new species of Agelanius from southern Chile.

\section{MATERIAL AND METHODS}

The specimens examined, all pinned, were collected in Isla Surgidero (Chiloé Province, Región de Los Lagos, Chile, S $43^{\circ} 35^{\prime} \mathrm{O} 74^{\circ} 20^{\prime}$ ) and Lago Puyehue (Osorno Province, Región de Los Lagos, Chile, S $40^{\circ} 38^{\prime}$ O 72 $36^{\prime}$ ). Specimens are deposited in the Instituto de Entomología, Universidad Metropolitana de Ciencias de la Educación (UMCE), Santiago, Chile. Female genitalia was removed and macerated in a solution of $10 \% \mathrm{KOH}$ and subsequently mounted on slides in Canadian balsam. Drawings were made with a camera lucida. The terminology of adults follows that of McAlpine (1981).

\section{RESULTS}

\section{Agelanius chiloensis sp. $\mathbf{n}$.}

DiAGNosis Eyes with sparse hairs. Frons divergent ventrally. Frontal callus with keel-shaped median projection and with a groove in the middle. Ocellar triangle with vestigial ocelli. Basal flagellomere with dorsal projection. Mesoscutum dark brown, bearing two short longitudinal grayish stripes. Wings hyaline, without appendix on R4. Abdomen dark brown with median pale brownish pilose triangles.

DesCRIPTION OF THE HolotyPe Female: Length 11.5 $\mathrm{mm}$; wing $11.0 \mathrm{~mm}$.

Head: black eyes without bands, with sparse and long brownish hairs (Fig. 1a). Frons pale brown, with grayish tomentum, darker on the ocellar triangle, bearing long, abundant black hairs. Frons narrow, divergent; frontal index 2.3. Frontal callus pale brown, with keel-shaped median projection, short and with groove in the middle, not extending more than half the height of the front, not touching subcallus (Fig. 1b). Ocellar triangle small dark brown, with vestigial ocelli. Posterior border of the head gray; vertex with short proclinate black hairs. Subcallus yellowish tomentose, with black hairs. Clypeus and genae gray-whitish tomentose, genae with long blackish hairs, clypeus bearing brownish short hairs laterally. Beard with long whitish gray hairs. Scape of antenna gray, basally with grayish tomentum and with long black hairs for all surface. Pedicel concolorous, with short black hairs. Basal flagellomere dark brown with dorsal projection, apical flagellomeres dark brown (Fig. 1c). Maxillary palpi slender and elongate, with grayish pollinosity and abundant short black hairs (Fig. 1d). Proboscis black, labella black, large and fleshy (Fig. 1a).

Thorax: mesoscutum dark brown, bearing anteriorly two short longitudinal grayish stripes. Notopleural lobe brownish gray, with long dark brown and gray hairs. Scutellum dark brown, without pruinosity, with long grayish hairs only on lateral border. Pleura brownish-gray, with long grayish hairs. Legs dark brown, coxae and femora grayish, with long gray hairs, tibiae and tarsi with abundant short black hairs. Wings hyaline, Sc and R1 setose, without appendix on R4. Basicosta bare. Halteres dark brown. Squamae concolorous with base of wing.

Abdomen (Fig. 1 e): dark brown dorsally, with short brown hairs, middle of tergites lighter, with pale brown hairs and with median pale brownish pilose triangles; lateral border of tergites with long pale brown hairs. Sternites brownish-gray with abundant short black hairs.

Genitalia: cerci subcircular, with short hairs (Fig. 1f). Tergite $X$ subrectangular, sclerotized (Fig. 1f). Tergite IX subtriangular (Fig. 1f). Gonapophysis projected distally, slightly concave, with long and abundant bristles (Fig. 1g). VIII sternite with slightly straigh base (Fig. 1g). Genital fork with base narrow and convex, with long and slender spermathecal ducts (Fig. 1h).

Male: unknown

Referred Specimens. Holotype: female, Chile, Chiloé Province, Isla Surgidero, Archipiélago Guapiquilan, 23.I.1987, J. Solervicens Col. Paratype: 3 females Lago Puyehue 23.I.1992, C.R. González Col. Holotype and Paratypes housed in 

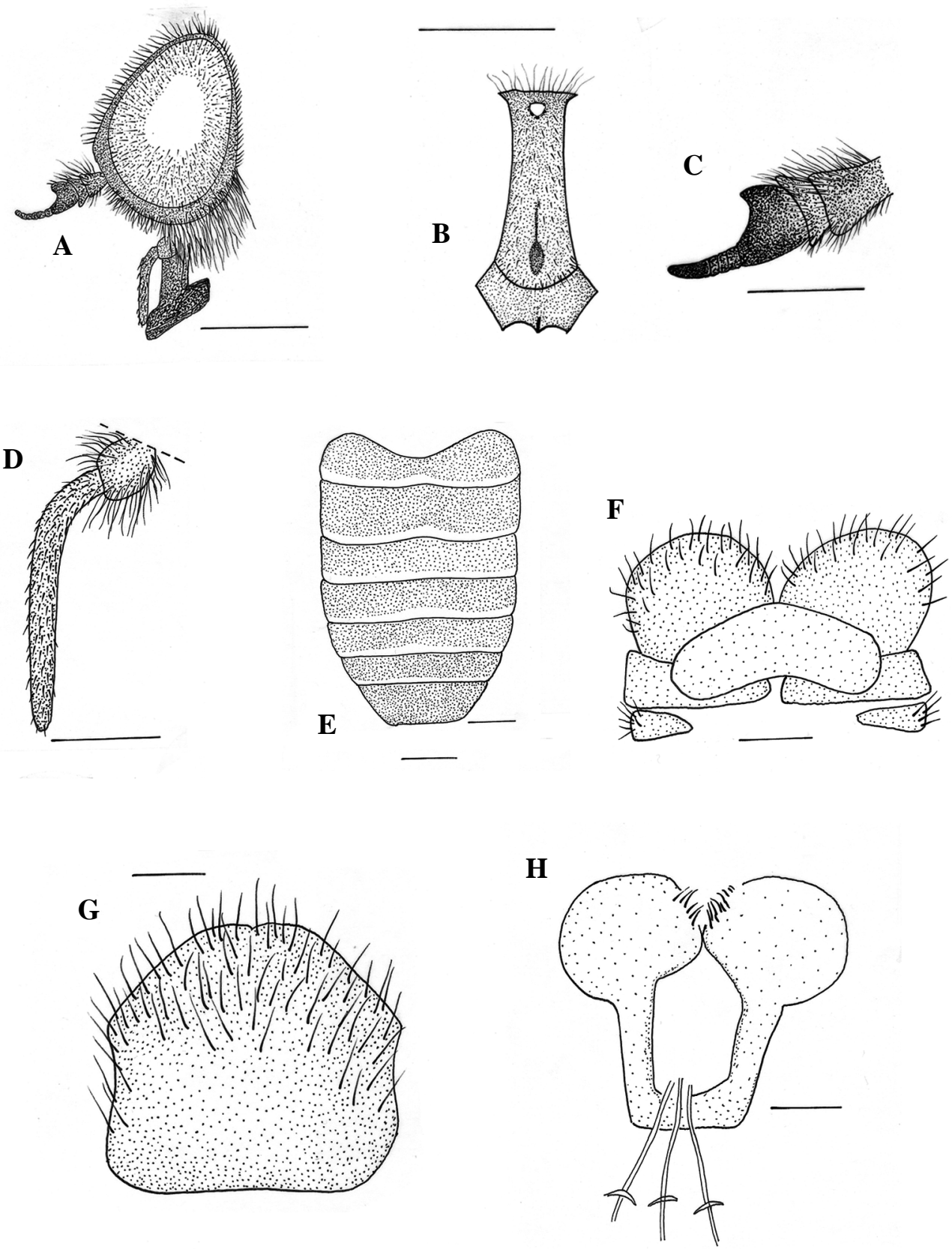

Figure 1. Female of Agelanius chiloensis sp. $\mathrm{n}$. A: head in side view (scale bar $=1.0 \mathrm{~mm}$ ); B: frons (scale bar $=1.0 \mathrm{~mm}$ ); $\mathrm{C}$ : antenna (scale bar $=0.5 \mathrm{~mm})$; D: maxillary palp $($ scale bar $=0.5 \mathrm{~mm})$; E: abdomen in dorsal view $($ scale bar $=1.0$ $\mathrm{mm})$; F: tergite IX, X, cerci, and hypoproct (scale bar $=0.3 \mathrm{~mm})$; G: gonapophysis and VIII sternite $(\mathrm{scale}$ bar $=0.2$ $\mathrm{mm})$; H: genital fork and spermathecal ducts (scale bar $=0.3 \mathrm{~mm}$ ).

FiguRA 1. Hembra de Agelanius chiloensis sp. n. A: cabeza en vista lateral (escala =1,0 mm); B: frente (escala $=1,0$ $\mathrm{mm})$; $\mathrm{C}$ : antena $($ escala $=0,5 \mathrm{~mm}) ; \mathrm{D}$ : palpo maxilar (escala $=0,5 \mathrm{~mm})$; E: abdomen en vista dorsal $($ escala $=1,0) ; \mathrm{F}$ : tergitos IX, X, cercos e hipoprocto (escala $=0,3 \mathrm{~mm}$ ); G: gonapófisis y VIII esternito (escala = 0,2 $\mathrm{mm}$ ); H: horquilla genital y ductos espermáticos (escala $=0,3 \mathrm{~mm}$ ). 
Agelanius chiloensis, new species of horse fly from Chile: González, C.

the collection of Instituto de Entomología, Universidad Metropolitana de Ciencias de la Educación, Santiago, Chile.

ETYMology The specific name refers to the region, Chiloé, where specimens of the type series were collected.

Comparison A. chiloensis exhibits generalized features characteristic of the genus. A. chiloensis is similar in general appearance (frons divergent, basal flagellomere with dorsal projection, and with two anterior longitudinal stripes) to A. philippii Rondani from central and southern Chile; but A. chiloensis differs from $A$. philippii in the following external characters: eyes with sparse hairs, shape and color of frontal callus, wings hyaline, shape of gonapophysis, and genital fork with base convex. A. chiloensis also resembles A. cortesi (González) but the latter differs in having the eyes with abundant gray hairs, front parallel-sided, frontal callus black, ocellar triangle with three well-developed ocelli, a dark gray mesoscutum, and smoky wings.

\section{DISCUSSION}

The genus Agelanius currently comprises 11 species distributed in the southern part of South America, in the central Chile and Subantarctic subregions (sensu Morrone 2001); the majority of the species of Agelanius are endemic to these regions. This area was greatly affected by Pleistocene climatic events. During the Last Glacial Maximum (ca. 18,000 years) glaciers were present in the Andes and the central valley, reaching the eastern foothills of the Chilean costal range between the $39^{\circ}$ and $44^{\circ} \mathrm{S}$, north of the $39^{\circ} \mathrm{S}$ they were restricted to the Andes, and to the south of the $44^{\circ} \mathrm{S}$ glaciers reached the Pacific coast (Villagran 1990). The Pleistocene glacial changes affected the biota of southern Chile (e.g., Smith et al. 2001; Villagran 1990); however, for the moment the effect on Agelanius remains unknown.

There are no known published generic phylogenies for any of the subfamilies of Tabanidae. Coscarón \& Philip (1967) commented on possible relationships within Agelanius, but the species of this genus have never been subjected to a formal cladistic analysis. Phylogenetic studies are needed to clarify if the morphologic resemblance of $A$. chiloensis to A. phillipii and A. cortesi is due to shared ancestry o convergence. Similarly, the historical biogeography of the genus cannot be understood until relationships among Agelanius species are inferred.

\section{ACKNOWLEDGEMENTS}

To John F. Burger (University of New Hampshire, USA), Steve A. Marshall (University of Guelph, Canada), and two anonymous reviewers for suggestions and help in editing the English version.

\section{BIBLIOGRAPHY}

Coscarón, S. \& C.B. Philip. 1967. Revisión del género Dasybasis Macquart en la Región Neotropical (Diptera: Tabanidae). Revista Museo Argentino Ciencias Naturales "Bernardino Rivadavia", Entomología 2: 15-226.

Coscarón, S. \& C.R. GonZÁlez. 1991. Tabanidae de Chile: Lista de especies y clave para los géneros conocidos de Chile (Diptera: Tabanidae). Acta Entomológica Chilena 16: 125-150.

FAIRChILD, G.B. 1969. Notes on Neotropical Tabanidae XII. Classification and distribution, with keys to genera and subgenera. Arquivos de Zoologia, Sao Paulo 17(4):199-255.

FAirchild, G.B. \& J.F. Burger. 1994. A catalog of the Tabanidae (Diptera) of the Americas South of the United States. Memoirs American Entomological Institute 55:1-249.

GoNZÁLEZ, C.R. 1999. A revision of southern neotropical genera related to Dasybasis Macquart, 1847 (Diptera: Tabanidae: Diachlorini). Memoirs Entomology International 14: 137-194.

GoNZÁLEZ, C.R. 2000. Dasybasis elquiensis, a new species of horse fly from northern Chile (Diptera: Tabanidae: Diachlorini). Memórias do Instituto Oswaldo Cruz 95(5): 629-632.

GoNZÁLEZ, C.R. 2004. Description of adults and immature stages of Agelanius fuscus, a new species of horse fly from Central Chile (Diptera: Tabanidae: Diachlorini). Studia Dipterologica, 11(1): 211217.

GonzÁLEZ, C.R. 2006. Agelanius burgeri, a new species of horse fly from south Chile (Diptera: Tabanidae) Zootaxa 1364: 59-64

González, C.R. \& A.A. Henry. 1996. Dasybasis (Agelanius) cortesi, a new species of horse fly from Chile (Diptera: Tabanidae: Diachlorini). Memórias do Instituto Oswaldo Cruz 91(6): 733737.

KRÖBER, O. 1930. Tabanidae In: Diptera of Patagonia and South Chile. British Museum (Natural History) 5(2):106-161 
Gayana 73(1), 2009

MACQUART, J. 1847. Diptères exotiques nouveaux ou peu connus 2e. supplément. - Mémoires de la Société royale des Sciences, de l'Agriculture et des Arts, Lille 1846: 21-120.

McAlPINE, J.F. 1981. Morphology and terminology-adults. In : J.F. McAlpine et al. (Coordinators): Manual of Nearctic Diptera 1:9-63; Research Branch, Agriculture Canada (Monograph $\mathrm{N}^{\circ} 27$ ).

Morrone, J.J. 2001. Biogeografía de América y el Caribe M \& T. Manuales y Tesis SEA, vol. 3, Zaragoza, $148 \mathrm{pp}$.

Rondani, C. 1863. Diptera exotica revisa et annotata, 99 pp, 1 plate. Modena. [Also published under the title "Dipterorum species et genera aliqua exotica". - Archivio per la Zoologia l' Anatomia e la Fisiologia (1863) 3(1):1-99 (1864); Modena.]

Smith, M.F., D.A. Kelt \& J.L. Patton, 2001. Testing models of diversification in mice in the Abrothrix olivaceus/xanthorhinus complex in Chile and Argentina. Molecular Ecology 10(2): 397-405.

Stone, A. 1944. Some Tabanidae from Venezuela. Boletín Entomología Venezolana 3(3): 125-138

Villagran, C. 1990. Glacial climates and their effects on the history of the vegetation of Chile: a synthesis based on palynological evidence from Isla de Chiloé. Review of Palaeobotany and Palynology 65:17-24.

Recibido: 23.10.08

Aceptado: 18.05 .09 